Jolanta Żelazna

Uniwersytet Mikołaja Kopernika, Toruń

e-mail: jot_zna@uni.torun.pl

\title{
Heidegger: metafizyka czy hermeneutyka?
}

DOI: http://dx.doi.org/10.12775/RF.2017.004

\begin{abstract}
„Dziwne usiłowanie, by wykazać, że wartości są obiektywne, samo nie wie, co robi. [...] Myślenie według wartości jest tu i wszędzie największym bluźnierstwem, jakie można pomyśleć $[\ldots]^{* \prime \prime}$
\end{abstract}

Powyższe słowa nie wyrażają odpowiedzi na jedno z pytań zadanych Heideggerowi przez Jeana Beaufreta, nie mają też usprawiedliwiać gestu, którym piszący z góry odrzuca zamiar podtrzymania słowa $h u-$ manizm w obiegu języka filozofii. Jeśli do czegoś miałoby się ono jego zdaniem odnosić, to chyba i raczej do tych, którzy nie wierza, że „takie nazwy, jak „logika”, ,etyka”, fizyka”, pojawiają się dopiero wtedy, kiedy zanika pierwotne myślenie"1. A przecież, powiada Heidegger, „Grecy w swym wielkim okresie myśleli bez tego rodzaju tytułów"2.

List do J. Beaufreta został rozbudowany, przeformułowany i opublikowany ${ }^{3}$, kiedy Heidegger zdał sobie sprawę z faktu, że przedłuża-

* M. Heidegger, List o humanizmie, w: Budować mieszkać myśleć, Czytelnik, Warszawa 1977, s. 111.

1 Ibidem, s. 78-79.

2 Ibidem, s. 79.

3 M. Heidegger, Brief über den "Humanismus", Francke Verlag, Bern 1947, nast. Vittorio Klostermann, Frankfurt a/Main 1949. Tekst Listu powstał około dziesięć lat po zakończeniu przez Heideggera seminarium poświęconego filozofii Nietzschego, a co za tym idzie, po dogłębnym przemyśleniu kwestii 'wartości', 'przewartościowania' ich hierarchii i sensowności 'myślenia według wartości' w odniesieniu do różnych dziedzin życia. Opracowanie notatek do seminarium ukazało się dopiero w roku 1961 (Martin Heidegger, Nietzsche, t. 1-2, Stuttgart 1961, przekł. polski: M. Heidegger, Nietzsche, PWN, t. 1, Warszawa 1998, t. 2, Warszawa 1999). 
jące się powojenne milczenie, obrastające legendami i interpretacjami mającymi za podstawę jego polityczne zaangażowanie $\mathrm{w}$ latach 30., prowadzi do pogłębiania procesu, przed którym ostrzegał Nietzsche: „Die Wüste wächst: weh dem, der wüsten birgt!"”. Nie tylko adresat Listu, gdyż skoro on, to zwłaszcza inni, nie uczestniczący na co dzień w myśleniu istotnym, upadający na świat, winni otrzymać odpowiedź. Heidegger mógł być rozczarowany tym, że Beaufret dołączył do nich, nie myślących dość, by potrafili samodzielnie określić się w swoim byciu, że stając pośród nich, niejako w ich imieniu domagał się nazwy, która by im ich wskazała i przywróciła im miejsce pośród tych i takich, którzy ją utworzyli.

Cóż się właściwie zdarzyło? Kim są adresaci Listu? Jak to się dzieje, że sięgają po słowo wyrosłe w kwitnącym ongiś, ale dziś już martwym języku, nie słysząc, że brzmi głucho i wstawiane w rozmaite frazy, nie nabiera ani nie oddaje żadnego znaczenia? Dlaczego, kiedy wreszcie się o tym przekonują, wzywają filozofa, by im to znaczenie, ów nieznany sens "przywrócił" (comment redonner un sens au mot 'humanisme'5)? Żądanie to jest równie wykonalne, jak prośba o zwrot czasów utraconego dzieciństwa, z którym wojny światowe uporały się zbyt wcześnie, nie pozwalając nasycić się w pełni jego beztroską.

A jednak brzmi w nim poważny, spiżowy ton, niemalże groźba: Herr Heidegger, domagają się ci obcy mu ludzie, postawmy sprawę po męsku: skoro nie odpowiedział pan w porę na pytanie o etykę $e^{6}$, przyszedł czas zdać sprawę z kwestii fundamentalnej - pytamy teraz o ludzi, ludzkość, człowieczeństwo. Nie zadowoli nas byle zdanie, którym można uciszyć pospólstwo; pytania, Herr Heidegger, nie zadaje teraz masa, die Leute, people, tylko die Menschen, men: comment redonner un sens au mot 'humanisme'.

„Przywrócenia” można domagać się od kogoś, kto zawłaszczył, odebrał, zatrzymał i nie zwrócił, albo od tego, w czyjej władzy leży zaprowadzenie sprawiedliwości. Czego oczekują ci, w imieniu których przemawia Beaufret? Czyżby pragnęli znów poczuć się depozytariuszami sensu "humanizmu”? Czy rzeczywiście odkryli, że od dawna przypada im rola kustoszy, strzegących zabytkowych ram słowa, z których ktoś faszysta-Heidegger? - wyciął cenną treść „człowieczeństwa”? Co, jeśli w ogóle cokolwiek, łączy wszystkie wymienione kwestie - nienapisaną „etykę", polityczne decyzje filozofa, duchowe wykorzenienie szczęścia-

4 „Pustynia rośnie, biada, w kim się kryje!” (F. Nietzsche, Tako rzecze Zaratustra, Nakład Jakóba Mortkowicza, cz. II, Warszawa 1905, s. 428).

5 Ibidem, s. 78.

6 Anegdota ta powtarza się w niemal wszystkich biografiach intelektualnych Heideggera, zob. np. P. Dybel, „Panie Heidegger, kiedy Pan napisze etykę?”, w: Heidegger dzisiaj, „Aletheia”, 1990, nr 1(4), s. 326. 
rzy, którym dane było przeżyć, gdy inni ginęli bez własnej winy i bez sensu? Czy można to zrozumieć?

Heidegger nie daje za wygrana; próbuje raz jeszcze dać do z-rozumienia. Metodycznie, ab ovo wykłada dzieje "humanizmu" rozpoczęte według jego rozumienia w czasach, gdy z pnia greki wyrastała nowa gałązka. Aby przetrwać, język filozofii musiał przedzierać się przez bujną oczywistość zwrotów, $\mathrm{z}$ dawien dawna pławiących się w świetle zrozumiałości i celować $w$ prześwity pomiędzy słowami, uciekając się do dwu-znaczności, podążając za zmienną łaskawością nastrojów, ciekawości i gadaniny istot rozumnych. To, co w tym względzie mówi o nas Sein und Zeit, dotyczy także Greków; podobnie jak nasze, także ich wybory językowe podlegały niepojętej władzy mowy.

Stając wobec pozornego, lecz dręczącego problemu 'początku filozofii', Heidegger konstruuje mit o „będących, ugodzonych przez Będące". Tym pierwszym, jak to pokazuje jego fenomenologia, przysługiwać musi konstytutywna dla wszelkiego mówienia, myślenia i poznania 'otwartość', pozostałym - niewinna nieskrytość. I otwarte, i nieskryte 'bywają', ich współzależność nie przeciwstawia ich sobie; razem należą w mowie do „będących”. Forma imiesłowu, rzeczownika-i-czasownika sprzęgniętych w jednym wyrazie i w jednej myśli, zadowalała przed-filozoficznie mówiących Greków i zdawała się wystarczać im do codziennego obchodu świata. Heidegger powiada jednak, że ten świat, zastany jako już-będący albo nawet - któż to może wiedzieć? - samo 'Będące', które go fundowało, występuje ku 'otwartym' z darem: jako otwarci, zostali oni zagadnięci ${ }^{7}$, sprowokowani do „wypowiedzenia swojej praw$\mathrm{dy}^{\prime \prime}$. Nie 'całej' ani 'szczerej', lecz - swojej: w tym zwrocie widać, co się wydarzyło.

Zagadnięcie otworzyło epokę podobnie, jak młody pęd otwiera sobą czeluść pnia, kiedy wypuszcza on ku światłu gałązkę: przyjęcie daru przez zagadniętych miałoby być nie czym innym, jak wyrażeniem istoty wydarzenia, otwarciem mowy dla myślenia, które dotąd pozostawało nieme. Jak każda odrośl, także i język utworzony dla wyrażania ludzkiej prawdy będzie uczestniczył w odsłanianiu i zasłanianiu, w poszukiwaniu prześwitów światła, w ujawnianiu-siebie wobec 'otwartości' i w zatajaniu się przed natarczywością ciekawości, gadaniny i dwuznaczności. Język wczesnej filozofii greckiej nie był językiem władzy, partii, masy ani tłumu.

7 Istotę tego wydarzenia (das Ereignis) List przybliża słowem an-sprechen, zawierającym mocne wskazanie na relację, a nie na sam tylko akt mówienia. Polski przekład Józefa Tischnera dramatyzuje ansprechen, czyniąc „ugodzenie” myślenia "wezwaniem do wypowiedzenia swojej prawdy", zob. M. Heidegger, List..., op. cit., s. 76-77.

8 Ibidem, s. 77, kurs. J. Ż. 
Ponieważ nie zrozumiano go, gdy w Sein und Zeit rozjaśniał sens alethei, a naukę o grze w prześwit, jaką zasłanianie toczy z odsłanianiem, wciąż mylono z teorią prawdy-obecności, Heideggerowi nie pozostało nic innego, jak wrócić w Liście do odległej tradycji greckiej, gdyż łacińskie 'homo' i 'humanismus' powstały według niego w reaktywnej od-powiedzi na pra-greckie anthropos, którego ludzkiej prawdy-aletheia nie oddaje prawda-veritas.

Różnica ta jest dziejowo znamienna i decydująca. 'Będący' zagadnięci o ich prawdę najwyraźniej przyzwolili na zaczepkę, a co najmniej pojęli, że ich zagadnięto. Zanim jednak bycie (das Sein) związało się z istotą człowieka w myśleniu ${ }^{9}$, sprawiając, że możliwe stało się i zagadnięcie, i odpowiedź, trzeba było, by 'otwarte', którym jest dla siebie każdy $\mathrm{z}$ nas, stało się dla nas nie-skryte i wy-stawiło siebie 'jako takie' w oczekiwaniu na imię.

Kreśląc mit o 'swoich' Grekach, Heidegger czyni z nich herosów zdolnych sprostać nieludzkim wyzwaniom. W ludzkim świecie ludzie nadają imiona tym, którzy sami nie potrafią mówić i wszystkiemu temu, co się jawi. W tym znanym nam świecie 'od zawsze', 'od niepamiętnych czasów' nazywamy siebie ludźmi. Kto nadał nam takie miano? Cóż za naiwne pytanie; ten, kto miał do nas prawo, kto nas stworzył. Greków Heideggera nie stworzył jednak Bóg: oni nic o tym nie wiedzą. Kto ma więc do nich prawo? Powyższego pytania postawionego dziś greckim filozofom nie zadowoli garść mitologicznych (p)odpowiedzi. Heroiczni 'Grecy Heideggera' sami wydobyli swoje imię, sprowokowani albo i zagadnięci o nie wprost przez 'Będące'. Ukazało się im w rysie, w rozpadlinie pomiędzy (metaksy) będącym tu-oto 'otwartym', a 'Będącym'-w-prześwicie, 'jeszcze-nie-jawnym', zaledwie się zapowiadającym.

Wystarczy jednak moment rozproszenia, chwilka nieuwagi, mrugnięcie powiek, przesunięcie wzroku stąd - tam, żeby to, co jeszcze nie ujawnione, stało się już-straconym. Chcąc ujrzeć nie-skryte, trzeba trwać nieporuszonym, nie rozglądać się, nie wiercić i nie gapić. Kto tak potrafi? Zapewne sztukę tę znają myśliwi wypatrujący zwierzyny. Oni jednak nie bywają przez nią zagadywani. Zagadniętym może zostać ten, kto nasłuchując, nie tropi, lecz słucha, kto gotów jest od-powiedzieć, a nie ot, powiedzieć, skoro nauczono go mówić.

W takiej nasłuchującej gotowości od-powiadania wyraża się istota myślenia. To ono pozwala, dopuszcza (lässt), by 'Będące' nie zagadywało na próżno, lecz mówiło wprost do tego, kto usłyszy i usłucha. Przywołać znaczy wezwać po imieniu, tak jak Adama wezwał jego Bóg; jednak Adam nie był Grekiem, a Grecy nie bywali przyzywani w taki sposób. Zanim greckie nasłuchujące od-powiadanie stanie się gotowe odpowiadać, wpierw musi wsłuchać się $\mathrm{w}$ mowę natury rozlegającą się

9 Ibidem, s. 76. 
'tu-oto' i z jej brzmienia wybrać dźwięki, z których złoży sobie swoje własne imię. Greckie ucho upodobało sobie szczególną melodię: początkowe dźwięczne aN! złamane, jak drzewce włóczni, w złowieszczym THRo i gasnące $\mathrm{w}$ syku fali, walczącej z nadmorskim piaskiem - possss. Usłyszawszy mowę własnej istoty, posłuszny swemu przeznaczeniu, anthropos gotów jest teraz wysławiać swój świat.

Istota tego świata jawi mu się pod postacią physis, natury żyjącej $\mathrm{w}$ rozdwojeniu. Jej zjawiska pozostają $\mathrm{z}$ sobą $\mathrm{w}$ stanie permanentnej wojny, która jednak nie prowadzi do z-wyrodnienia i wy-naturzenia, lecz oglądana z dystansu, przybiera postać kosmosu, ładu wyrażającego wewnętrzny logos wszech-rzeczywistości. Odkrywszy tę podwójną prawdę bycia, zagadnięty przez nią, 'Grek Heideggera' znajduje siebie na rozdrożu. Odpowiadając, musi zdecydować o sobie: albo jak inne, nie-mowne zwierzęta, pozostanie pod bezwzględną władzą natury, albo od-powie jej 'własnym' prawem i zdobędzie się na bezprzykładną próbę wzniesienia się ponad jej stan. 'Zagadniętym' o ich prawdę nie wystarczało naturalne, zwierzęce przeznaczenie protoplastów kolejnych, jeszcze nie zrodzonych ludzkich pokoleń. Swoją decyzję wyrazili słowem zobowiązującym wszystkich noszących imię anthropos, by czynili 'tak, jak’ czyni natura. Posłuszni prawu, które dla siebie ustanowili, Grecy postępują śladami physis uważnie, jak myśliwi stawiający stopy przy śladach zwierzęcia, bacząc, by ich nie zatrzeć w pyle ścieżki.

Postępowanie trop w trop za wzorem, na-śladowanie go, od-twarzanie następstw i zwrotów kosmicznych form po to, by stworzyć coś, na co nie zdobyła się natura, wymaga i posłuszeństwa, i zuchwałości, umiejętnego decydowania o tym, kiedy i jak zejść ze ścieżki, którą chadza Mistrzyni i o tym, jak zaznaczyć obok swój ślad, wreszcie odwagi, by zwrócić się tam, gdzie brak tropów. Heidegger cofa pytającego o ‘humanizm' do tego momentu opowieści, w którym powinna ona trafnym słowem uchwycić źródłowy gest wyboru, decyzję, umożliwiającą określenie rodzaju relacji, jaką człowiek nawiąże z naturą. Ten wybór znamy jako mimesis, na-śladowanie. W słowie tym zawarła się kwintesencja wiedzy i samowiedzy ówczesnego człowieka: wiernego prawu odstępcy, zuchwałego naśladowcy.

$\mathrm{Ci}$, w imieniu których Beaufret zadał pytanie Heideggerowi, podobnie jak i on sam, nie sięgali tak daleko. Współczesnego człowieka dręczy wszak problem homo ${ }^{10}$ i nie obchodzą go Grecy. Jednak Heidegger pozostaje nieustępliwy i nastawia naszą uwagę na dziejowy moment zwrotu, kiedy to decyzje podjęte $\mathrm{w}$ grece wtapiają się w ukształtowaną

${ }^{10}$ O tym, że jest to problem aktualny, dobrze zaświadcza widoczna dwuznaczność tego słowa; problem "homo” jest nam współczesny i nagli, by znaleźć jego Lösung - rozwiązanie, ale też rozpuszczenie, zluzowanie go z funkcji wartownika uparcie przyglądającego się naszym poczynaniom. 
przez inne wybory łacinę. Hellenizujący się Rzymianie nie potrzebowali greckiego określenia człowieczeństwa ani nie wyrazili źródłowej samo-wiedzy w pojęciu łączącym posłuszeństwo i zuchwalstwo, wierność i odwagę odstępstwa. "Homo humanus stał w opozycji do homo barbaru$s^{\prime \prime 11}$, Rzymianin - w opozycji do Greka, póki go nie wchłonął; po czym, by się nim nie zatruć albo nie rozdwoić, zdecydował kroczyć po jego śladach, zacierając je - stał się po-śledni. Arche Greka, samoświadomość jego człowieczeństwa, wyraziła siebie dwojako: wprost - jako anthropos, a w relacji z naturą jako mimesis. Ta podwójność stała się jego losem: jako własną los wyznaczył mu dziedzinę pośrednią (metaksy) 'pomiędzy' tym, co zwierzęce w człowieku, co imituje naturę, a tym, ku czemu się on odwraca, naśladując naturę we własnych swych dziełach: ku boskiej sferze logosu.

Rzym zdobywa samoświadomość przez odróżnienie, biorąc za punkt odniesienia barbarzyńcę, zwącego siebie anthropos: 'wierny w odstępstwie', 'zdolny trwać pomiędzy'. Obywatel nie może być tak dwulicowy; jego istotę określa prawo, arche Rzymu: jednak nie logos, lecz ius i lex. Wszelkie odstępstwo od niego, przekroczenie wytyczonej przez nie granicy staje się $\mathrm{w}$ rzeczy samej wystąpieniem $\mathrm{z}$ człowieczeństwa: wszak ius i lex pochodzi od i stosuje się do istot rozumnych. „Pierwszy humanizm, mianowicie rzymski oraz wszelkie odmiany humanizmu od tamtych czasów aż do teraz zakładają najogólniejszą „istotę" człowieka jako samą przez się zrozumiałą. Człowiek został uznany za animal rationale"12: zwierzę, zdolne rozumieć prawo.

Tak opowiedziana Heideggerowska historia początków humanizmu przeoczyła klasyczne greckie filozoficzne próby wyartykułowania 'istoty' człowieka. Celowo, gdyż jako odległe w czasie od pierwszych, pre-filozoficznych wysiłków tworzenia mowy, należą one do abstrakcyjnego, narzędziowego języka metafizyki, narosłego niczym łyko na miękkim rdzeniu słów. Na tę szkodliwość 'technicznej interpretacji' w odniesieniu do żywego doświadczenia myślenia Heidegger zwrócił uwagę w początkowym akapicie Listu, gdzie rozważał istotę 'działania': nie potrafimy pomyśleć i wyrazić go inaczej, aniżeli przeciw-stawiając działającego z-działanemu, myślącego - z-myślonemu, podmiotu - przedmiotowi. Naszym myśleniem władają logika i gramatyka, także przecież z-działane, skoro nie należą do rzeczy zrodzonych przez naturę. Kto je stworzył

11 M. Heidegger, List..., op. cit., s. 83. Nota bene - bárbaros jako źródło, barbarus jako naśladownictwo źródłowego słowa, pokazuje dość dobrze dzieje owego „zwrotu" czy też zwrot dziejów, wiraż, na którym pewne treści wcześniejszej samowiedzy 'wypadły z toru' i zostały zastąpione innymi ujęciami człowieczeństwa albo pozostawiły po sobie luki. Jedną z nich Heidegger wskazuje w słowach motta cytowanego w tym tekście.

12 M. Heidegger, List..., op. cit., s. 85. 
i do czego zostały prze-znaczone? Pytania te, skierowane w przeszłość, pozostają bez odpowiedzi i ten właśnie brak nadaje im wagę: „dziś jesteśmy w stanie dopiero przeczuć, co się wtedy stało. Odpowiedzialność za uwolnienie mowy od gramatyki ku bardziej pierwotnym istotowym zrębom spoczywa na myśleniu i twórczości poetyckiej. Myślenie to nie tylko "l'engagement dans l'action" przez byt i dla bytu w sensie tego, co rzeczywiste $\mathrm{w}$ obecnej sytuacji. Myślenie to l'engagement przez prawdę bycia i dla niej. Dzieje bycia są wciąż przed nami, a nie za nami. Niosą one i określają wszelką conditio et situation humaine"13.

Jeśli greka z czasów przed-filozoficznych uznałaby myślenie za rodzaj czynności, jego wytwory musiałyby zapewne podlegać równie rzeczowej ocenie, jak efekty działania według reguł innych sztuk wytwórczych, techne. Tymczasem język mówi co innego, odróżniając techne i poiesis: wczesno-greckie słowotwórstwo nie zostało wymierzone w cel, telos: kres, ustanie działania i wysiłku, osiągnięcie, które stało się do-sięgnięciem, u-chwyceniem, pojęciem-pojmaniem istoty rzeczy, zawładnięciem nią niczym jeńcem - wszystko to nie wchodzi w grę w mowie. Zwłaszcza nie tam, gdzie stale porusza się ona między zatajaniem i ujawnianiem; nie pod berłem alethhei.

O mówieniu i myśleniu myślano i mówiono jeszcze nie raz; jednak dopiero w czasach rozkwitu filozofii ateńskiej pomyślano i powiedziano o nim rzecz wcześniej niesłychaną: jako działanie nie jest ono rozmową z natura, naśladującym odpowiadaniem na jej przyjacielskie zagadywanie, lecz rozważnym „robieniem czegos'”, czego nie potrzebuje ani natura-physis, ani natura ludzka. Nawet jednak, gdyby tym „czymś" miało być zaledwie 'przypomnienie' oglądanych niegdyś, nieziemskich, nieporuszonych idei rzeczy, to zuchwalstwo pomysłu nakazującego odebrać rzeczom natury status doskonałych pierwowzorów naśladowanych podług ludzkich umiejętności i dostrzec w nich tylko kopie bytów wymaga postawienia pytania o warunki, bez których taka rewolta myśli przenigdy nie doszłaby do skutku.

Heidegger postawił je sobie, zanim napisał List. Odpowiedzi znajdujemy $\mathrm{w}$ rozprawach o fragmentach pism Heraklita i Parmenidesa oraz w Przezwyciężeniu metafizyki $i^{14}$. Nie wydaje się, by chociaż częściowo zdawały one sprawę z tego, "co się wtedy stało". Z rozważań Heideggera można się domyślać, że jego zdaniem grecki namysł nad językiem poprzedził próby określenia istoty myślenia: „, $\lambda \dot{\gamma} \gamma \varepsilon เ v$ zawsze oznacza dla Greków zarazem: przedkładać, prezentować, opowiadać, powiadać.

13 Ibidem, s. 77.

14 Zob. M. Heidegger, Odczyty i rozprawy, Wydawnictwo Baran i Suszczyński, Kraków 2002. Źródłem rozpraw o filozofii Heraklita były wykłady Heideggera z czasów wojny, tekst o Parmenidesie należy tematycznie do wykładów Was heißt Denken? (1951-1952). 


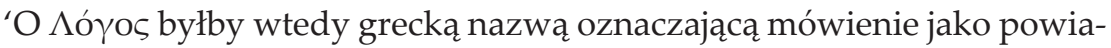

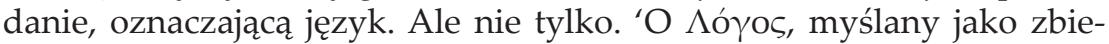
rający kład, byłby myślaną po grecku istotą wieści (Sage). Język byłby wieścią. Język byłby skupiającym-dopuszczaniem-przed-kładania-się czegoś wyistaczającego się w jego wyistaczaniu. Rzeczywiście: Grecy mieszkali w tej istocie języka, nigdy jej jednak nie pomyśleli"15.

Pomiędzy Heraklitem i Platonem rozpościera się odstęp czasu sięgający niemalże stu lat ${ }^{16}$ i nie mniejszy szmat przestrzeni dzielący Efez i Ateny. Idąc tym tropem i szukając śladów "tego, co się tu stało", należałoby widzieć w Heraklicie myśliciela ukazującego logos naśladowany w ludzkiej sztuce jako kosmos, prawo zmienności widoczne w życiu natury. Pomiędzy nim i Platonem, po raz pierwszy tak wyraźnie czyniącym z natury kopię logosu przesuniętego poza granice kosmicznego ładu, dzieje postawiły dwie postaci: Kratylosa, zwolennika pierwszego i nauczyciela drugiego z nich, oraz Sokratesa, poszukiwacza językowych form stosownych do wyrażania 'tego, co samo wystarcza'. To wtedy, gdy słuchał Sokratesa, Platonowi „stało się coś” takiego, że przypisał językowi i myśleniu jedno wspólne zadanie - (d)ostatecznego przypominania i celnego ujmowania tego, co nie może być zapomniane przez wzgląd na dobro duszy.

„Stać się" musiało, gdyż według Heideggera ani Grecy nie znający jeszcze filozofii, ani Heraklit nie pomyślał języka, mowy i mówienia

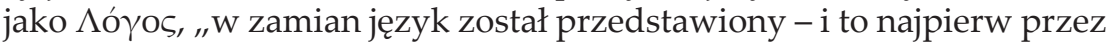
Greków - od strony artykulacji jako $\phi \omega v \eta ́$, jako brzmienie i głos, fonetycznie $^{\prime \prime 17}$ i mimetycznie, $w$ nasłuchiwaniu zagadywania i w odpowiedzi na nie. Kto i o co zagadnął filozofów ateńskich tak, że w odpowiedzi ustanowili nowe prawo nakazujące myśleniu jego własna misję? Czyżby porządkując naturę, myślenie to natrafiło nad brzegiem którejś sadzawki na Narcyza i zachwycone jego autotelicznym erosem zapragnęło, tak jak on, przeglądać się w sobie? Czy myślenie $w$ czystej postaci to umiłowanie mądrości zrodzonej w myśleniu myślenia, $\mathrm{w}$ autoerotycznym akcie filozofowania, czy przeciwnie, to nasłuchująca gotowość bycia zagadywanym i zagadująco-odpowiadającym?

„Jeżeli chcemy nauczyć się czystego doświadczania istoty myślenia, co zarazem znaczy spełniania go, musimy się uwolnić od jego technicznej interpretacji. Początki takiej interpretacji pojawiają się już u Platona

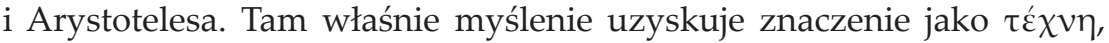

15 M. Heidegger, Logos, w: idem, Odczyty i rozprawy, op. cit., s. 203.

16 Tyle mniej więcej czasu oddziela powstanie Akademii Platońskiej (387 r. p.n.e.) od daty śmierci Heraklita (480 r. p.n.e.).

17 M. Heidegger, Logos, op. cit., s. 203. 
jako proces zastanawiania się nad czymś w stużbie czynu, robienia czegoś"18.

Jeśli myślenie, sztuka naśladowania natury w dźwięcznych frazach mowy, wypowiadało kosmiczny ład powszechnej zmienności, nie celując - jak chce Heidegger - w kład, w ustalające, nieruchome wy-powiedzenie, czyli w logos przed-kładający wieść o istocie natury, to przesunięcie techne, języka - wy-tworu służącego wy-powiadaniu, w miejsce poiesis, naśladowczego od-powiadania naturze, zapoczątkowuje epokę meta-fizyki. W niej dokonuje się wydziedziczenie samowiedzy ludzkiej ze sfery fizykalnej immanencji, z wspót-istnienia z naturą i przesunięcia jej $\mathrm{w}$ transcendencję obcego naturze bycia-duszą. Istotą tego ruchu jest także re-aktywne odniesienie do tradycji.

Platon nie tworzy mocą własnej prawodawczej decyzji, lecz przesuwa - Sokratesa nad Kratylosa, wtóre przed pierwotne, a tak ustanowiony porządek wy-kłada jako źródłowy, trwały i niezmienny. Wobec czego powziął taki zamiar? Co nadało mu impuls przeobrażający odtąd myślenie myślenia w "robienie czegoś użytecznego”, w wypalanie znaczeń słów, dotychczas giętko przemykających się w mowie ku światłu ludzkiego rozumienia, tak jak wypala się gliniane naczynia, chcąc, by już zawsze i trwale pozostawały niezmiennymi miarami zawartych w nich treści? Dobro, agaton, ujęte przez Sokratesa w definicji, staje się miarą tego, "co samo wystarcza", prawda przeistacza się z gry ukrywania i nie-skrytości w byt niezmiennej, „wzorczej” idei, byt zmienia się z nagła w "to, co jest", a jest awansuje do rangi nieporuszonego i niezmiennego trwania. Wszystkie te narzędzia myślenia powstały w sprzeciwie wobec ruchu, słówka krnąbrnego, aczkolwiek konsekwentnego w swym uporze zawracania myśli ku jej źródłowej epoce, ku czasom Heraklita.

Techniczny język właśnie rozkwitłej filozofii pozorował posłuszeństwo wobec zamiarów myślicieli, którzy zapragnęli ustawić użyteczne terminy w ordynku znaczeń, przysądzonych im w definicjach. Nie pytany o jego arche, porządkowany przeciw własnemu źródłu, zastawił na swych zarządców pułapkę. Z-luzowany z roli naśladującego od-powiadania naturze, wydziedziczony z obszaru poiesis, język-jako-język nie prowadzi nas już w pobliże Będącego, które zagaduje 'otwartych', strzegących jego dziedziny, lecz wiedzie nas wprost - do języka. W filozoficznym użyciu Arystotelesa termin 'ruch', objaśniany przez niego jako 'zmiana', sam pozwala zaistnieć zmianie jako 'postaci ruchu'. Wytwarzanie 'narzędzi językowych' pomyślane jako techne doprowadziło ateńskich inżynierów myślenia do wykrycia błędnego koła w mowie potocznej i do uznania go za jej źródłowa, wrodzoną strukturę.

18 Zob. M. Heidegger, List..., op. cit., s. 77, kurs. J. Ż. 
Opisywane przez Heideggera związki techne i poiesis analizowano tak często, że w końcu weszły do zestawu współczesnych pojęć filozoficznych, stały się sloganem, aż wreszcie to, co próbował nam naświetlić, przestało niepokoić, zatarło się w gadaninie. Nie potrzebujemy już odpowiedzi na pytania podnoszone przez pokolenie czasów II wojny; udręka Beaufreta nie jest naszym problemem - nas frapują własne, o wiele bardziej intrygujące kwestie, jak na przykład ta, czy Heidegger był nazista, czy dostępne w publicznym obiegu dokumenty - słynna mowa rektorska i komentarze do niej ${ }^{19}$, listy, archiwalia z lat 30. i 40. - mają wystarczającą wartość, by na ich podstawie można było wykazać stopień współodpowiedzialności filozofa za przebieg naszej historii?

Żądając wyjaśnienia stopnia jego winy, nie troszczymy się o przebieg zdarzeń, gdyż ten został już, jak sądzimy, ustalony; zamiast tego domagamy się podstaw dla naszej historii w źródłowym znaczeniu greckiego słowa: dla opowieści, którą przekazano nam słowami zasłyszanymi w czasach, gdy interesujące nas zdarzenia nic jeszcze nie wiedziały o swym dalszym biegu. Słowa wciąż nie nadążają za dziejami, mamy je stale spóźnione; używamy wszak cudzych, zasłyszanych zwrotów, a własne tworzymy dla zapamiętania już zaistniałych faktów. Te, którymi Heidegger odpowiedział na wezwanie Jeana Beaufrete'a, miały w jego zamyśle przywołać pierwotne znaczenia, a wraz z nimi - ustanowić i otworzyć pytanie o tych, którzy te znaczenia mozolnie tworzyli, posłuszni swemu przeznaczeniu i nasłuchujący, jak przemawia do nich natura. Nasze pytania o nas samych stoją przecież na niezbywalnym, dziejowym fundamencie ich rozstrzygnięć i opierają się na nim bez względu na to, czy jesteśmy świadomi tego faktu, czy też nie.

Akcja opowieści naszkicowanej w Liście o humanizmie została rozpięta pomiędzy dwiema postaciami dramatu, o który pytał Beaufret. Wspólnym losem jego pokolenia stało się wydziedziczenie z człowieczeństwa. Po wydarzeniach II wojny nie było już wiadomo, czy nadal pozostaje ono znakiem rodowym ocalonych, czy wolno im widzieć się wśród pokoleń grupujących się wokół herbu „humanitas"; nie potrafiono też objaśnić sobie, do czego owo szlachectwo uprawnia ani do czego miałoby obligować. Tragedia, którą szkicuje Heidegger, choć temu, co się wydarzyło, daleko do artyzmu greckich dramatów, rozgrywa się według niego między anthropos i homo.

Żadnej z tych figur nie powołała do istnienia natura, nie zastaliśmy ich w świecie tak, jak zastajemy deszcz i wiatr. Bezimienni, którzy na-

19 Zob. np. M. Heidegger, Samoutwierdzenie się niemieckiego uniwersytetu, w: Heidegger dzisiaj, "Aletheia” op. cit., s. 365-369 albo „Przegląd Polityczny”, 2009, nr 97/98, s. 114-119; idem, Rektorat 1933/34. Fakty i myśli, "Aletheia”, op. cit., s. 370-379. 
zwali siebie tymi mianami, rozpoczęli naszą historię nie w naszym, ale we własnym imieniu. Dlatego poszukiwanie odpowiedzi na pytanie o „humanizm” bez pamięci o tamtym początku naszych dziejów całkowicie zmienia zarówno sens pytania, jak i możliwej odpowiedzi na nie. Heidegger zdaje się czytać zadane mu pytanie w przeświadczeniu, że pierwszy początek naszej historii został skutecznie zasłonięty przez ten drugi, 'właściwy' nam, łacińsko-chrześcijański, podobnie jak wczesne odczasownikowe rozumienie 'prawdy' (nie-skrywania) ustąpiło miejsca temu 'właściwemu', którym posługujemy się do dziś.

Czy jednak początek jest czymś, co możemy wybierać? Czy zasłonięcie i w efekcie - zapomnienie go, a w zamian - uznanie za 'nasz' początek rzymskiego źródła zamiast greckich korzeni naszego losu, nie przesądza o niemożliwości 'zwrócenia' nam sensu istoty człowieczeństwa, gdyż nigdy go nie utraciliśmy? Tego sensu - ‘humanitas' - nie zapomnieliśmy ${ }^{20}$ przecież nawet podczas wojen; od czasów rzymskich przez wieki średnie aż do współczesności działania zbrojne dokonują się w Europie tak humanitarnie, jak to tylko możliwe - wobec jeńców, internowanych cywilów i ludności podbitych krajów. Nie co innego, jak właśnie 'humanitas' i humanitaryzm skłoniły nas do eks-terminowania niesamodzielnych i zależnych w swym istnieniu chorych i wszelkich od nas 'innych', gdyż, jak wiadomo, okropności naszych wojen dotknęłyby ich tak brutalnie, że nasza wrażliwość nie mogłaby tego znieść.

Jednak źródło, z którego tak meandrycznym nurtem płynie sens 'humanitas' i humanitaryzmu, rzymskie pojęcie człowieka, Heidegger chce ukazać jako ujście strumienia, ciągle jeszcze ukrytego wobec naszej dziejowej świadomości. Homo to akwedukt, cywilizacyjna forma regulująca ciśnienie podziemnego nurtu tradycji greckiej, technicznie, ale nie w dźwiękach, poetycko, lecz w kamieniu wykute koryto, które według twardego prawa Rzymu zawiaduje ludzkimi losami. Prawo to spoczywa na trwałej podstawie łacińskiej prawdy - veritas; bez niej, bez trwałej odpowiedniości porównywanych z sobą członów, byłoby ono zapewne 'miększe', przypuszczalnie bardziej słuszne aniżeli twarde, ustępliwsze wobec okoliczności, ale Rzym nie stałby się sprawnie zarządzanym imperium.

Pytanie Beaufreta zostało 'rozmontowane'. Heidegger, świadomy, o co ono pyta i w jak znaczącym momencie stało się publicznym zagadnieniem, zajmuje miejsce 'w rysie', we wspomnianym wcześniej 'pomiędzy', gdzie zamierza utrzymać się bez względu na cenę, jaką się mu wy-

20 Liczba mnoga tego czasownika i zaimek 'my' w dalszym fragmencie tekstu zostały tu wybrane dla podkreślenia wspólnej ludzkiej odpowiedzialności za bieg zdarzeń, zarówno ze strony ich czynnych uczestników, jak i biernych obserwatorów. Można ją rozumieć w sensie Jaspersowskiego problemu winy (die Schuldfrage), 'metafizycznie' wpisanej w egzystencję. 
stawi za jego upór. Wpierw jednak przypomina, skąd rysa ta pochodzi i jak głęboko sięga zapomnienie jej istnienia.

'Humanitas', oś pytania, zostaje z niego wymontowane i ‘wystawione' na widok. Dopiero ten akt ujawnia, co się pod nim kryło, a raczej - co zostało nim zakryte: pęknięcie, szczelina rozpościerająca się 'pomiędzy' tymi, którzy swoją wspólnotową identyfikację czerpią z rzymsko-łacińskiego źródła, a barbarzyńcami. Greckie, często rozdwajające się ścieżki ich, barbarzyńców, myślenia, nawykłe do mimetycznego dialogu, rozdzielane przez Sokratesa, domagającego się od swych rozmówców wyboru pomiędzy "tak" i "nie", prostowane przez Arystotelesa, szkicującego ich przebieg od przyczyn wprost do skutków, ostatecznie zatarła armia pojęć łacińskiej filozofii. Jej marsz z przeszłości ku naszym czasom dokonał się po trakcie, zbudowanym z gładko ciosanych płyt, takich jak 'humanitas'. To, że zagadujące pytanie Beaufret'a zatrzymało się 'na płaszczyźnie drogi' rzymskiego myślenia, Heidegger odczytuje jako akt co najmniej zapomnienia, jeśli nie zaparcia się faktycznego pochodzenia, tak pytającego, jak i tych, w imieniu których on pyta. W Liście nie znajdziemy ani słowa, które można by uznać za przyznanie się do błędu i winy, brak w nim oczekiwanego powszechnie 'przepraszam', dobitnie uznającego odpowiedzialność i rozpoznającego leżący u jej podstaw błąd myślenia. Nie napisał go wyznający skruchę filozof. $Z a-$ miast tego zostajemy wciągnięci w obszar metaksy, każe się nam stanąć i wytrwać wobec 'zadania myślenia', osobliwej zagadki, której znaczenie mogłoby się zacząć rozjaśniać, gdybyśmy u-trzymali w dystansie napór dwóch potężnych sił: potrzeby zaufania, przyzwolenia, by rzeczy biegły zgodnie z porządkiem natury i potrzeby kontrolowania porządku, tak, by rzeczy służyły nam, zamiast nas zaskakiwać. List zdaje się wykręcać od odpowiedzi, mówić długo i zawile o tym i o owym, zmieniać temat, uciekać się do metafor, zupełnie, jakby jego autor usiłował przerzucić własną moralną i polityczną odpowiedzialność na językowe decyzje jakichś tajemniczych poprzedników, zmuszające nas dziś do przyjęcia perspektywy, z której nie sposób rozróżnić i nie pomylić zadań religii, filozofii i nauki. Tak też nierzadko go odczytywano.

Jednocześnie nie ma w nim także śladu próby uciekania od odpowiedzialności. Heidegger ma dość odwagi, by unieść i odsunąć na bok grobową płytę z inskrypcją 'HUMANITAS', wejść w czeluść 'pomiędzy' epokami i stąd, ze wspólnej ziemi niczyjej, wyciąga po nas rękę. O etyce, jeśli nadal będziemy się upierać, że znaczy ona 'myśleć według wartości', będzie z nami rozmawiał, gdy staniemy po stronie niczyjej, gdyż dopiero to miejsce uwalnia nas, faktycznie dając do wyboru. Tam, gdzie nie wybrano jeszcze, co znaczy 'rozumieć', lecz zagadnięto, czy zdarzało nam się już kiedyś zrozumieć i zrozumiałość utracić, odpowiedź rodzi się ze słuszności, nie zawsze pokrywającej się z jedno-znaczną prawdą. 
Z-rozumiana odpowiedź, a tylko taka ma swą wagę, dochodzi do głosu, który niekoniecznie musi być słowem.

Sztuka rozumienia, hermeneutyka, okazuje się z gruntu grecka: zakorzenia się 'pomiędzy' słowami pytania i odpowiedzi, w otwartości, w rysie pomiędzy tak i nie. Heidegger od dawna powtarzał, że jednym $\mathrm{z}$ modi mowy jest milczenie, ta cisza, która niczego się nie domaga, tylko lässt - przyzwala, dopuszcza, zgadza się na..., czyni sposobność, by... Tak pomyślana, hermeneutyka musi być pierwszą filozofia, przed fizyką i metafizyka, przed etyką i polityką.

\section{Bibliografia}

Dybel P., Panie Heidegger, kiedy Pan napisze etyke??, w: Heidegger dzisiaj, „Aletheia", 1990, z. 1(4).

Heidegger dzisiaj, „Aletheia”, 1990, z. 1(4).

Heidegger M., Brief über den „Humanismus”, Francke Verlag, Bern 1947, (Vittorio Klostermann, Frankfurt a/Main 1949).

Heidegger M., List o humanizmie, w: idem, Budować mieszkać myśleć, Czytelnik, Warszawa 1977.

Heidegger M., Logos, w: idem, Odczyty i rozprawy, Wydawnictwo Baran i Suszczyński, Kraków 2002.

Heidegger M., Nietzsche, Bd. 1-2, Stuttgart 1961.

Heidegger M., Nietzsche, PWN, t. 1, Warszawa 1998, t. 2, Warszawa 1999.

Heidegger M., Odczyty i rozprawy, Wydawnictwo Baran i Suszczyński, Kraków 2002.

Heidegger M., Rektorat 1933/34. Fakty i myśli, w: Heidegger dzisiaj, „Aletheia”, 1990, z. 1(4).

Heidegger M., Samoutwierdzenie się niemieckiego uniwersytetu, w: Heidegger dzisiaj, "Aletheia”, 1990, z. 1(4) albo „Przegląd Polityczny”, 2009, nr 97/98.

Nietzsche F., Tako rzecze Zaratustra, Nakład Jakóba Mortkowicza, cz. II, Warszawa 1905.

\section{Streszczenie}

\section{Heidegger: metafizyka czy hermeneutyka?}

Pytany po wojnie o rozumienie człowieczeństwa, humanizmu, etyki, odpowiedzialności, Heidegger udzielił obszernej i wieloznacznej odpowiedzi w Liście o humanizmie. Dodatkowe objaśnienia zawarte są też i jego innych powojennych artykułach, odczytach i szkicach (esej zbiera je i zestawia z głównymi wątkami Listu). Europejczyk pytany o humanizm zostaje odniesiony do tradycji Rzymu 
i odcięty od greckich korzeni swoich dziejów. W grece, a nie w łacinie zapadały jednak fundamentalne rozstrzygnięcia naszego wspólnego myślenia. Odcinając się od nich i zapominając je, pozbawiamy się gruntu i stajemy na skraju przepaści (Abgrund). Heidegger pytał o medium myślenia, mowę i język. Wskazywał na odmienność greckiego i łacińskiego nazywania mowy i na konsekwencje zapomnienia o związkach poiesis i techne. Przypominał o różnicy w nazywaniu i rozumieniu "prawdy” - aletheia i veritas, o wieloznaczności „myślenia” i jego greckim źródle logos. W eseju przywołane zostały poglądy Heideggera uzasadniające jego zdaniem konieczność wycofania się przed odpowiedzią na pytanie o kondycję człowieka i humanizm. Będzie ona pochopna i szkodliwa, jeśli wpierw nie zdecydujemy się wysłuchać tego, co mówią dzieje naszego myślenia.

\section{Słowa kluczowe}

Heidegger, Beaufret, humanizm, człowiek, techne, poiesis, język, prawda

\section{Summary}

\section{The Metaphysics or a Hermeneutics}

When asked after the war about the understanding of humanity, humanism, ethics and responsibility, Heidegger gave an extensive and ambiguous answer in Letter on Humanism. Additional explanations are included in his post-war papers, read-outs and sketches (the essay collects them and compares to the main themes of Letter). An European asked about humanism is re-directed towards the tradition of Rome and cut off from the Greek roots of his history. However, it was in Greek, not Latin, that the fundamental solutions to our common thinking were taken. By cutting ourselves away from and forgetting them, we turn ourselves groundless and stand on the brink of a chasm (Abgrund). Heidegger asked about the medium of thinking, the speech and the language. He pointed out to the diversity of the Greek and Latin naming of speech and to the consequences of forgetting about the connections of poiesis and techne. He reminded of the difference in naming and understanding the 'truth' - aletheia and veritas, about the ambiguity of 'thinking' and its Greek root of logos. The essay brings up the views of Heidegger that, in his opinion, legitimise the necessity of backing away from the answer to the question of human condition and humanism. It would be rash and dangerous, unless we first decide to listen to what the history of our thinking says.

\section{Keywords}

Heidegger, Beaufret, humanism, man, techne, poiesis, language, truth 